Western Kentucky University

TopSCHOLAR®

GFCB Working Paper Series

Gordon Ford College of Business Documents

and Special Projects

$9-1-2004$

\title{
Membership on Editorial Boards and Rankings of Schools with International Business Orientation
}

\author{
Kam C. Chan \\ Western Kentucky University, johnny.chan@wku.edu \\ Hung-Gay Fung Dr. \\ University of Missouri-St. Louis, fungh@umsl.edu \\ Pikki Lai \\ Alcott-Routon Consulting, plai@alcottrouton.com
}

Follow this and additional works at: https://digitalcommons.wku.edu/gfcb_wrkg_pap

Part of the Corporate Finance Commons, E-Commerce Commons, Finance and Financial Management Commons, International Business Commons, and the Management Information Systems Commons

\section{Recommended Citation}

Chan, Kam C.; Fung, Hung-Gay Dr.; and Lai, Pikki, "Membership on Editorial Boards and Rankings of Schools with International Business Orientation" (2004). GFCB Working Paper Series. Paper 3. https://digitalcommons.wku.edu/gfcb_wrkg_pap/3

This Article is brought to you for free and open access by TopSCHOLARß. It has been accepted for inclusion in GFCB Working Paper Series by an authorized administrator of TopSCHOLARß. For more information, please contact topscholar@wku.edu. 


\title{
Membership on Editorial Boards and Rankings of Schools with International Business Orientation
}

\author{
Kam C. Chan \\ Leon Page Professor of Finance \\ Department of Finance \\ Gordon Ford College of Business \\ Western Kentucky University \\ Bowling Green, KY 42101 \\ Tel: (937) 229-4591; fax: (937) 229-2477 \\ Email: Johnny.Chan@wku.edu \\ Hung-Gay Fung \\ Dr. Y.S .Tsiang Professor of Chinese Studies \\ College of Business Administration \\ University of Missouri-St. Louis \\ 8001 Natural Bridge Road \\ St. Louis, MO 63121 \\ Tel: (314) 516-6374; Fax: (314) 516-6420 \\ Email: fungh@msx.umsl.edu
}

\author{
Pikki Lai \\ Senior Analyst \\ Alcott-Routon Consulting \\ Franklin, TN 37067 \\ Tel: (615) 261-7100 \\ Email: Plai@AlcottRouton.com \\ September, 2004 (this version)
}

We thank three anonymous referees, Raj Aggarwal (editor), Julius Johnson, and David Ricks for helpful comments, and Bob Baumann, Jennifer Dennis and Patricia Peat for editorial assistance. 


\title{
Membership on Editorial Boards and Rankings of Schools With International Business Orientation
}

\begin{abstract}
Using four-year data (1990, 1994, 1998, and 2002), we have provided a ranking of schools with international business (IB) orientation based on the membership on editorial boards of 30 leading international business journals. Participation on editorial boards of quality journals is highly selective, and should provide a quality indication of the schools. Both quality unadjusted and adjusted board membership based ranking are calculated in this study. Several interesting findings are worth noting. First, U.S. schools play a significant leadership role among the leading IB programs. Second, the findings of this study also show the major contribution of non-U.S. schools, which confirm the importance of the global nature of the IB discipline. Third, the topranked schools share a number of characteristics. Finally, the correlation among different ranking criteria can be low, particularly for the top-ranked schools, suggesting that care should be exercised in interpreting school ranking.
\end{abstract}




\section{Membership on Editorial Boards and Rankings of Schools With International Business Orientation}

\section{Introduction}

The objective of this study is to rank schools with international business (IB) orientation based on faculty representation on journal editorial boards. IB orientation refers to schools either with IB programs or with faculty conducting research in IB areas. To this end, we use an academic program's representation on editorial boards to proxy for the reputation of an international business orientation of a school. Membership on the editorial board of a quality journal is highly selective. A greater number of faculty in an institution's IB program serving on editorial boards of quality IB journals would indicate higher quality of the IB program. This approach has been used in marketing [Kurtz and Boone (1988)], in statistics [Gibbons (1990)], in economics [Gibbons and Fish (1991)], in accounting [Mittermaier (1991)], and in finance [Kaufman (1984) and Chan and Fok (2003)].

Using the editorial board representation, we provide a ranking of IB programs. We analyze the list of editorial board members for the top thirty IB journals in 1990, 1994, 1998, and 2002. The list of the selected IB journals has been well documented in Dubois and Reeb (2000) as the prime research outlets for IB researchers. We further extend earlier studies by including journal quality and IB programs, and identify a number of common characteristics among leading IB programs.

Our study on school ranking related to international business is interesting for several reasons. The AACSB-International (Association to Advance Collegiate Schools of Business), a business program accrediting organization, uses the editorial board representation information as part of its evaluation of professional services. Media such as Business Week and the Financial 
Times rank business schools, while the U.S. News and World Report regularly provide rankings of U.S. business schools in a number of disciplines (including international business). However, with the exception of the Financial Times, the annual rankings of Business Week and U.S. News and World Report include only U.S. colleges. As international business is a truly global discipline, one would also expect colleges in the rest of the world to have a large influence on the development of the IB discipline. Thus, it is important to include non-U.S. colleges in the IB ranking. In addition, the media use subjective criteria in ranking schools. ${ }^{1}$

This study, using an editorial board representation approach, provides an alternative and objective approach to the ranking of schools with IB orientation. ${ }^{2}$ Our study includes ranking of schools outside the U.S. and uses information from 1990-2002 to provide a more recent ranking of schools with IB programs and covers a larger set of IB journals with explicit consideration of journal quality. Several interesting findings are worth noting. First, U.S. schools play a significant leadership role among the leading IB programs. Second, we find a major contribution of non-U.S. schools to school ranking, confirming the importance of the global nature of the IB discipline. Third, the top-ranked schools share a number of characteristics, such as a stand-alone IB program, faculty publishing in the top-tier IB journals or ranked MBA programs. Finally, the correlation among different ranking criteria can be low, particularly for the top-ranked schools, suggesting that care should be exercised in interpreting school ranking.

\footnotetext{
${ }^{1}$ For example, U.S. News and World Report asks business school deans and program heads to nominate up to 10 programs for excellence in each of the areas listed. The 10 schools receiving the most votes are ranked as leaders of these programs in a particular business discipline. For details, see http://www.usnews.com/usnews/edu/grad/rankings.

2 Some business schools may not necessarily have a designated international business program, but they do have international business courses or faculty conducting research in international business.
} 
The organization of the paper is as follows. We first provide a brief literature review and a discussion on the research issue. Then we discuss editorial board membership data and the research methodology. Results of the empirical analysis along with their implications are presented. Finally, we conclude with some discussions on the limitations of our study and future research.

\section{Literature Review and Research Issue}

Rankings of schools provide important information for internal and external uses. Kaufman (1984), Gibbons (1990), and Chan and Fok (2003) provide detailed explanations for the use of rankings. As an internal yardstick, university administrators may use rankings for program evaluation, curriculum decisions, and even resource allocation. Promotion and tenure decision criteria may be related to rankings of programs involved. In addition, hiring departments may use rankings in employment decisions. For external purposes, schools typically publicize their good ranking to attract more qualified students, better faculty, and more financial donors.

Several approaches have been used to examine academic program ranking in the literature. The first approach is an opinion survey. Essentially, the survey approach uses questionnaires to ask opinions of a selected group of individuals regarding the ranking of schools in a business discipline. Ball and McCulloch $(1984,1988)$ and Nehrt (1987) have used the survey approach to rank IB programs. Opinion surveys are based on perceptions of the quality of academic programs among a selective group of individuals such as faculty, deans, or business executives. While perceptions of these selected groups are certainly useful, opinion surveys incur biases that are very difficult to correct in the survey design. Coe and Weinstocks (1983) and 
Mabry and Sharplin (1985) discuss various shortcomings of the survey approach in general and Douglas (1989) presents her criticisms on the findings of Nehrt (1987) in the context of ranking IB master's degree programs. In general, shortcomings and criticisms of opinion survey include the subjective nature of survey design imparted by researchers, the large number of nonresponses, the inability of respondents to gauge the changing quality of a program over time, and the question of whether the respondents are truly good representatives of the institutions.

Another approach to rankings in a specific functional discipline is to measure research output of each area. To provide a ranking of one functional area, many studies examine the research productivity of an institution's faculty or its doctoral graduates. Unlike the opinion survey, this approach is more objective. However, limitations of this approach include the assumption that quantity of research is the primary indicator [see Chan and Fok (2003)] and the approach usually ignores inter-disciplinary research outlets [see Chan, Chen, and Steiner (2002)]. There has been a plethora of ranking studies among various business functional areas -- for instance, in accounting [Cottingham and Hussey (2000)], in finance [Borokhovich, Bricker, Brunarski, and Simkins (1995) and Chan, Chen, and Steiner (2002)], in marketing [Powers, Swan, Bos, and Patton (1998)], and in economics [Conboy, Dusansky, Drukker, and Kildegaard (1995)].

In contrast, there are few research productivity-based studies in school ranking related to international business. Using publication data of nine leading journals ${ }^{3}$ from 1980-1989 and carefully selecting only IB articles to be included in their sample ${ }^{4}$, Morrison and Inkpen (1991) provide an IB school ranking based on research productivity. In their ranking, articles in two

\footnotetext{
${ }^{3}$ The nine journals are Journal of International Business Studies, Columbia Journal of World Business (now called Journal of World Business), Harvard Business Review, Journal of Marketing, Academy of Management Journal, Academy of Management Review, Journal of Marketing Research, Journal of Finance, and American Economic Review.

${ }^{4}$ For instance, there were only three articles selected from Journal of Finance and American Economic Review.
} 
journals (Journal of International Business Studies (JIBS) and Journal of World Business) constitute $86 \%$ of all "IB articles" in their sample. ${ }^{5}$ In a retrospective study of JIBS, Inkpen and Beamish (1994) also provide a ranking of schools with research productivity solely based on articles appearing in that journal from 1970-1994. While both Morrison and Inkpen (1991) and Inkpen and Beamish (1994) are informative, the studies are focused on one to two major IB journals only. Pierce and Garven (1995) survey a wide array of journal editors and provide information on 79 business journals that publish international research. Phene and Guisinger (1998) provide citation-based analysis on the development of JIBS, and confirm that it does well. Pierce and Garven (1995) is a publishing guide for authors, and Phene and Guisinger (1998) provide a recent evaluation of JIBS to suggest its status as the leading IB journal.

The research published in IB journals displays multi-functional interests, and thus raises the question of uniqueness of the discipline. Wright and Ricks (1994) provide an update to an earlier study of Nehrt, Truitt, and Wright (1970) regarding the scope of IB research, and conclude that IB research has extended into a broader range of functional areas and geographical areas. In addition to the studies of Morrison and Inkpen (1991) and Inkpen and Beamish (1994) on IB productivity, Chandy and Williams (1994) examine the influence of individuals and other business disciplines on IB research in JIBS, and conclude that management, economics, marketing, and finance disciplines have significant impacts on IB research, endorsing the multifunctional aspect of the IB discipline. In a survey study, Hult, Neese, and Bashaw (1997) find that five out of the top 40 marketing journals were international in nature, while a citation analysis of the leading management journals revealed that JIBS, an international journal, was the most cited journal in the management literature.

\footnotetext{
${ }^{5}$ Among 664 IB articles in the nine journals (in footnote 2), Journal of International Business Studies and Journal of World Business account for 571 articles.
} 
In some universities, the IB area is a stand-alone program, while in other universities, the IB area blends into other disciplines or is a sub-set of other disciplines. It is not surprising that in a recent comment and reply exchange, Dubois and Reeb (2000, 2001), in studying the pecking order of IB research outlets, maintain that IB research should maintain an inward focus, while Inkpen (2001) believes that IB research should extend into specific disciplines in order to gain greater legitimacy. Apparently, it is not easy and remains an issue for researchers to identify an objective measure to capture the nature of ranking IB programs.

In light of the issues above, the use of editorial board membership appears to be an objective and potentially useful measure that can benchmark research productivity (as board members are typically productive members who are research oriented) and the extent of international business programs (as board membership provides visibility to their schools). Because of the multi-functional nature of IB as a discipline, IB scholars have published in leading IB journals and other major journals focusing in different functional areas. This pattern of research may make the traditional approach of output analysis difficult because there are many journals that publish IB-related articles. Our editorial membership approach can potentially circumvent the difficulty. If an IB scholar publishes well (in IB and/or functional journals), he or she will likely be invited to join an editorial board of an IB journal. Hence, editorial board representation is useful in gauging the schools' research productivity. Using a regression analysis, we also examine whether board memberships can indeed reflect school reputation, research output, and nature of the IB programs. 


\section{Editorial Board Data and Ranking Method}

We examine the editorial board members of 30 leading international business journals. The list of these journals is reported in Appendix 1. A recent study by Dubois and Reeb (2000) include these 30 journals as the basis in ranking IB journals. The list contains journals with an explicit focus on IB topics (e.g., the Journal of International Business Studies and Journal of World Business) as well as journals in other disciplines with substantial international focus (e.g., Journal of International Marketing and Management International Review). The examination of journal editorial boards in 1990, 1994, 1998, and 2002 allows us to examine the quality of IB programs among academic institutions over a reasonably long time period.

To accommodate the argument that it may be more prestigious in serving at the Journal of International Business Studies than other journals, we use the journal impact factors to adjust for differential journal quality served by editorial board membership. Similar to Chan and Fok (2003), we calculate an editorial board index (EBI) by multiplying the impact factors of the 30 journals by the frequency counts of editorial board representation to generate a ranking. The EBI of an institution or individual is defined as:

$$
\text { EBI }=\sum_{i=1}^{30} \sum_{t=1}^{4} f_{i t} * I_{i t}
$$

where $f_{i t}=$ frequency of editorial memberships in the $i^{\text {th }}$ journal at time $t$; and $\mathrm{IF}_{\text {it }}=$ impact factor of the $\mathrm{i}^{\text {th }}$ journal at time $\mathrm{t}$.

The EBI index enables us to mitigate the effect of differential journal quality on IB program rankings using impact factors as weights. We have two methods to compute the impact factors. First, we follow the conventional methodology used by the Social Science Citation Index but focused only on five source journals (i.e., the Journal of International Business Studies, the 
Journal of World Business, International Business Review, Multinational Business Review, and Management International Review) as in Dubois and Reeb (2000). We constructed the new impact factors for 1990, 1994, 1998, and 2002 in order to match the year of editorial board memberships. The Social Science Citation Index impact factor for a journal at time $t$ is calculated by dividing the number of citations from articles of the source journal at time $t$ for articles published in the prior two years by the total number of articles published in that journal for the same period. For example, the 2002 impact factor for JIBS is the total citations that JIBS received from the five source journals in 2002 for JIBS articles in 2000 and 2001 divided by the total number of JIBS articles in 2000 and 2001. The impact factors using information for the prior two years for 1990, 1994, 1998, and 2002 are reported in Appendix 1. Apparently, JIBS has the largest impact factor. ${ }^{6} \quad$ A weakness in this analysis is that we use only five source journals and look into the citation patterns for two years before the citing articles for our impact factor calculations. Nevertheless, our reported impact factors of JIBS are consistent with the impact factors in Table 3 of Phene and Guisinger (1998), which has a median impact factor of 0.324 during 1981-1991. For robustness of the study, we also use information for the prior five years in counting article citations. This approach is different from the Social Science Citation Index but it allows a longer time horizon for articles to show their impact. ${ }^{7}$ The results are in Appendix 2.

When editorial board members associate with more than one affiliation, we divide the credit to each institution equally. For instance, if individual A is an editorial board member affiliated with two institutions $\mathrm{X}$ and $\mathrm{Y}$, we assign institutions $\mathrm{X}$ and $\mathrm{Y}$ half of the credit for the editorial board membership.

\footnotetext{
6 The largest impact factor of JIBS is 0.8649 , which has been checked to ensure accuracy.

7 We thank a reviewer for suggesting this to us.
} 
There are 103 editorial boards from 30 IB journals over the four years: 1990, 1994, 1998, and 2002. ${ }^{8}$ Specifically, there are 23, 27, 26, 27 editorial boards in 1990, 1994, 1998, and 2002 respectively. ${ }^{9}$ Among the 103 editorial boards for the four years, there are 3,542 editorial memberships consisting of 1,457 different individuals from 686 different institutions. ${ }^{10}$ These editorial board memberships include different titles such as managing editor, editor-in-chief, consulting editor, editor, associate editor, and members of editorial boards. We exclude staff members who have titles such as editorial assistants or assistant editors. There are 24 editorial board members with more than one affiliation.

\section{Empirical Analysis}

Table 1 displays the geographical location of editorial board membership for the international business discipline. Two points are noteworthy. First, as a region, North America dominates the IB field with 2,162.5 (63\%) editorial board memberships. Europe follows second with 838 (24\%) board memberships. Asia and Pacific countries rank third with 320.5 (9\%) members. It is interesting to note that other regions (South America, Africa and Middle East) also have a noticeable contribution to the profession (104.5 memberships).

Second, the top five countries with the largest board memberships are U.S. (1,991), U.K. (237.5), Canada (171.5), France (106.5), and Australia (96). Clearly, the U.S. plays the leading role in the IB profession with the largest number of board memberships and the highest number of different faculty. Non-U.S. schools as a whole make up 1,434.5 board memberships, which

\footnotetext{
${ }^{8}$ It is uncommon for editorial boards to change membership every year. Examinations of the board membership representation every four years should be able to capture possible changes among the journal editorial boards.

9 Some journals ceased publishing in the late 1990s and some had not started publishing until late 1990s,

10 There are 95 individuals with affiliations missing. We deleted them from the analysis.
} 
are competitive with the 1,991 memberships in the U.S. Thus, the significant contribution of schools in other countries to the IB profession cannot be ignored and underestimated. ${ }^{11}$

Table 2 provides a ranking of institutions by the number of editorial member representations in the 30 IB journals. We only show the top-50 rankings in Table $2 .{ }^{12}$ Column (3) provides the frequency counts of editorial board memberships. Other additional information (number of faculty and different journals) is also included to determine if a school has only a few or a large number of faculty serving on editorial boards. ${ }^{13}$ While we include non-academic institutions in the analysis, academic institutions dominate the top rankings. Several interesting points are worth noting.

First, the top five institutions are U.S. schools, suggesting the leading roles of U.S. schools in the international business program. There are 67 editorial memberships at Michigan State University, 65 memberships at New York University, 57 memberships at Columbia University, 55 memberships at American Graduate School of International Management (Thunderbird), and 52 memberships at the University of South Carolina.

Second, the number of different journals and individual faculty members are fairly evenly distributed over most of the ranked IB programs. Columns (4) and (5) present the number of different journals and the number of different individuals from each institution, which make up the editorial boards of the 30 journals. For instance, Michigan State University has editorial

\footnotetext{
${ }^{11}$ While the majority of the journals (23 out of 30 or $77 \%$ ) have editors from the U.S., there are only $58 \%$ (exclude Canada) of the editorial board members are from the U.S. It appears that US-based journal bias, if any, is not large. When we examine the affiliations of all the JIBS articles from 1990-2002, the affiliations of the non-US institutions share approximately $40 \%$ of all articles published. The JIBS publication patterns suggest that IB discipline depicts a genuine international scope in terms of author affiliations.

${ }_{12}$ A complete ranking is provided at the author's website.

${ }^{13}$ We do not normalize the frequency of editorial board memberships by the total number of faculty for two reasons. First, it is not practical or possible to know the number of IB faculty in early years in all the schools. Any count of IB faculty within each school may incur subjective bias because IB faculty are wide-spread in other functional areas and we need to subjectively determine if the faculty is indeed an IB faculty. Second, a school's IB reputation does not derive from a per capita basis. The name recognition is derived from all IB faculty as a group.
} 
representation on 17 of the 30 journals, and it has 28 different faculty members on the editorial boards of the 17 journals over the period of 1990, 1994, 1998, and 2002.

The results in Table 2 also suggest that a few programs are carried by a handful of individuals. Such examples would be John Carroll University (ranked 39 ${ }^{\text {th }}$ ) and Brigham Young University (ranked $49^{\text {th }}$ ) with the editorial board representation of one and two individuals respectively.

$<$ Insert Table 2 here $>$

Third, foreign institutions have a good representation on IB journal editorial boards, demonstrating the global nature of the discipline, a result consistent with Table 1 . Table 2 indicates that there are 15 foreign institutions on the top-50 list. That is, foreign schools, as a group, represent $29 \%$ of top rankings. ${ }^{14}$ However, there are only six non-U.S. schools ranked in the top-25, representing $24 \%$ of this group. This pattern confirms the dominant role of the U.S. schools in top rankings. The notable highest-ranked non-U.S. institutions are INSEAD $\left(7^{\text {th }}\right)$ in France, London Business School $\left(13^{\text {th }}\right)$ in U.K., the University of New South Wales $\left(14^{\text {th }}\right)$ in Australia, the University of Reading (19th) in U.K., Simon Fraser University $\left(19^{\text {th }}\right)$ in Canada, and Stockholm School of Economics $\left(25^{\text {th }}\right)$ in Sweden.

Finally, the 2002 international business program ranking by the U.S. News and World Report as of January 2003 (Column 6 of Table 2) differs sharply from those of our rankings. ${ }^{15}$ For example, the University of Chicago, which was ranked $17^{\text {th }}$ by the U.S. News and World Report, does not show up in our ranking. Many of the highly ranked U.S. and non-U.S. schools

14 Because of ties in schools, there are fifty-one schools in our ranking.

15 U.S. News and World Report offers IB schools ranking for undergraduate and graduate programs. This study uses their graduate school ranking here because they are supposedly more related to research and editorial boards. 
(e.g., INSEAD, Pennsylvania State University, Georgetown University, and Rutgers University) according to our board membership ranking are not in the rankings of the U.S. News and World Report.

The last column of Table 2 presents the most recent IB program ranking study by Morrison and Inkpen (1991). While Morrison and Inkpen’s ranking included non-U.S. schools, their relative ranking also differs from those of our results. The results in Table 2 do not consider the impact of differential journal quality. Most would agree that membership on the editorial board of a top journal, such as the Journal of International Business Studies, is more prestigious than membership on a less prestigious journal board.

Table 3 reports the new ranking for institutions adjusted by editorial board index (EBI (t2) and EBI (t-5)). EBI (t-2) is the editorial board index that reflects the impact factors incorporating prior two-year information (see Appendix 1), while EBI (t-5) reflects the impact factors with prior five-year information (Appendix 2). The top five institutions are the University of South Carolina, New York University, Georgetown University, the University of Reading, and the University of Pennsylvania using EBI (t-2). New insight is generated. First, one non-U.S. school, the University of Reading, is now ranked fourth. There are 19 non-U.S. institutions ranked in the top-50, which is more than those in Table 2. The more non-U.S. institutions being ranked in the top schools suggests that IB faculty in foreign institutions serve on better (or higher impact factor) IB journals, and the faculty in these foreign institutions have a good representation in quality journals.

$<$ Insert Table 3 here $>$ 
Second, a drastic shift of rankings for some schools can be observed. For example, Michigan State University, ranked $1^{\text {st }}$ in Table 2, is now ranked $7^{\text {th }}$ in Table 3. The University of Reading, a U.K. university, ranked $19^{\text {th }}$ in Table 2, is now ranked $4^{\text {th }}$ in Table 3 (using EBI (t-2)). These results illustrate the significant impact of different criteria used in ranking schools.

While there is a slight change in relative school ranking using EBI (t-5) as compared to EBI (t-2), there are no significant changes. However, several observations are worth mentioning with EBI (t-2) and EBI (t-5) using different years to compute the impact factors. First, there are more journals having non-zero impact factors with five-year prior information (see Appendix 2) as compared with those using two-year prior information (see Appendix 1). Second, the leading IB journals, such as JIBS, have more stable impact factors. Finally, the school rankings using EBI (t-2) and EBI (t-5) have a correlation coefficient of 0.9771, while the top 13 IB programs using EBI (t-2) and EBI (t-5) impact factors are essentially the same. Thus, it is not surprising that the literature uses the prior two-year information for rankings. Our results using prior fiveyear information further confirm the usefulness of using prior 2-year information suggested in the literature. The advantage of having more stable impact factors for some journals using the prior five-year information needs to be evaluated in light of the substantial cost of information collection.

An important issue pertaining to the rankings in Tables 2 and 3 is whether there are possible common characteristics shared by these leading IB programs. To this end, we conduct a regression analysis to examine the extent of editorial board participation for the top international business programs with some underlying important characteristics of schools. Our dependent variables are editorial board memberships, and two editorial board indices (using prior 2-year or 5-year information). We use the following characteristics as explanatory variables: (1) AACSB 
accreditation or not, (2) whether a public or private institution, (3) MBA program ranking, (4) whether the schools have stand alone IB programs, highest degree offered (to proxy IB program size), (5) location, and (6) research output from JIBS during $1990-2002^{16}$ (to proxy productivity if the schools are highly published). We collect data on these variables from the websites of the relevant schools, AASCB website, and published articles of JIBS for the period 1990-2002.

Table 4 Panel A presents the correlation coefficients among the variables used in the regression models. All the explanatory variables do not have high correlation coefficients among themselves while the three dependent variables all have high correlation coefficients. Table 4 Panel B reports the regression model results. We identify several variables that the leading IB programs share in terms of editorial board memberships and editorial board index. First, a standalone IB program and an IB doctoral program have a positive and significant coefficient in the editorial board members regression equation, implying that they improve scores of school ranking in terms of editorial board memberships. Second, a higher research productivity output (a large number of JIBS articles published) has a positive impact on scores of schools based on the number of editorial board memberships. The higher the research productivity of a school, the better rank the school could have based on either the editorial board membership or the editorial board index. Third, the MBA ranking variable is negative, implying that a school with a higher MBA ranking (i.e., a lower number) variable will have a higher ranked IB program (higher scores). These findings suggest that the top IB programs (in terms of more editorial board representation) share a number of characteristics such as having stand-alone IB programs, offering the doctoral degree, having a high MBA ranking, and having a highly published faculty. The regression results using EBI (t-2) and EBI (t-5) are similar in sign with the results using

\footnotetext{
${ }^{16}$ We hand-collected all article information from JIBS during 1990-2002 and calculated the research productivity of the schools in our sample. The top-50 IB programs according to the JIBS research output are reported in Appendix 3.
} 
editorial board memberships, but not significant in stand-alone IB program and IB doctoral program variables. We use variance inflation factors to detect multicollinearity problems among the explanatory variables for all the regressions in Panel B, Table 4. The factors are all below four, suggesting no multicollinearity problems among the explanatory variables. ${ }^{17}$

$<$ Insert Table 4 here $>$

Table 5 presents the rank correlation analyses among various rankings. Panel A reports the correlation for different criteria using all the institutions that have EBI (both academic and non-academic). The correlation between EBI (t-2) ranking (in Table 3) and editorial board ranking (Table 2) is 0.5203 for 332 institutions, EBI (t-5) ranking and editorial board ranking is 0.5883 for 526 institutions and 0.6808 for the top-25 IB programs.

Panel B of Table 5 reports the correlation between the ranking of U.S. News and World Report, Morrison and Inkpen (1991) and Inkpen and Beamish (1994) and the rankings in this study. The rank correlation of U.S. News and World Report with editorial board membership is 0.1565 and with EBI (t-2) is 0.2151. The top-25 schools in Morrison and Inkpen (1991) and the rankings in this study also have low correlation coefficients. The correlation coefficient is 0.1645 with editorial board memberships and 0.1430 with EBI (t-2) ranking. Lastly, the rank correlation coefficients between Inkpen and Beamish’s (1994) top-25 schools and the ranking editorial board membership and EBI (t-2) ranking are 0.2928 and0.3724, respectively. The results for EBI (t-5) are similar to those of EBI (t-2). Overall, the correlation coefficients in Panel B are low across different criteria, suggesting that rankings based on an opinion survey methodology, on only U.S. schools, or restrictive to one or two IB journals may be misleading.

${ }^{17}$ Please refer to http://raven.cc.ukans.edu/ kups/maillist/classes/ps707/2004/msg00057.html for details. 
Table 6 provides a list of leading IB professionals in terms of the number of editorial board memberships (Panel A) and EBI (t-2) (Panel B). ${ }^{18}$ In Panel A, the top five individuals are Raj Aggarwal, Erdener Kaynak, Tamer Cavusgil, David Ricks, and Jean Boddewyn. Panel B presents the impact factor-based EBI ranking. The top five individuals are Raj Aggarwal, Susan Douglas, Nancy Adler, Jean Francois Hennart, and Mark Cassion. The results in both panels indicate that Raj Aggarwal ranks at the top consistently, but the ranking of other individuals changes depending on the criteria used.

$<$ Insert Table 6 here $>$

\section{Summary and Implications}

We have ranked institutions according to the representation of their faculty on editorial boards of 30 leading international business journals. We consider that the editorial board membership on high-quality journals represents prestigious positions of the institutions and signals the academic reputation of the individuals. The number of membership representations on the editorial board is a good proxy for the quality of the program. Without adjusting for journal quality, the top five institutions are Michigan State University, New York University, Columbia University, American Graduate School of International Management (Thunderbird), and the University of South Carolina. Using the impact factor to adjust for journal quality in editorial board representation (EBI (t-2)), the top five institutions are the University of South Carolina, New York University, Georgetown University, the University of Reading, and the University of Pennsylvania.

\footnotetext{
${ }^{18}$ The individual rankings based on EBI (t-5) are similar to those of EBI (t-2). The detailed results are available upon request.
} 
In addition, school ranking, such as the one provided in U.S. News and World Report, entirely based on only U.S. schools can be misleading for the international business school discipline because international business is truly a global discipline. One striking result in our study is the leading role of the U.S. schools in the international business profession. However, the contribution of the non-U.S. schools as a group is shown to be equally important as their faculty representation on editorial board membership is very significant. Our study also suggests that the top IB programs share a number of characteristics such as having stand-alone IB programs, an IB doctoral program, high MBA ranking, and highly published faculty.

When school administrators use ranking as a managerial decision for fund raising and faculty promotion, care must be exercised in interpreting the ranking and the issues involved. Blindly following the ranking provided by media can be misleading, which is demonstrated in our study. The rank correlation between the survey ranking by U.S. News and World Report and board membership participation in this study is found to be very low.

\section{Limitations and Future Research}

Editorial board membership is not a perfect ranking criterion. There are limitations in our study. First, our study only covers a 12-year time span for the analysis. Clearly, a longer time span is preferred, if resources are available. Second, we used only five source journals in computing the impact factors. Although this approach has been used previously, a larger number of source journals (e.g., all 30 IB journals in our study) would be more desirable ${ }^{19}$. Third, when we calculate impact factors, we do not adjust for self-citations. An evaluation of this nature would illustrate whether or not self-citations would change the impact factors and the

\footnotetext{
${ }^{19}$ We use five journals in this study for two reasons. First, we try to follow the literature [see Dubois and Reeb (2000)]. Second, some journals in earlier years are not readily available in all university libraries and the cost of collecting all the information is prohibitive.
} 
outcomes. ${ }^{20}$ Fourth, good researchers may not choose to be on editorial boards due to time constraints or other reasons. As a result, limited participation on an editorial board does not necessarily imply that the non-ranked schools are of lesser quality. Last, it is evident that IB has gained substantially in the last few years and there are a number of IB articles appearing in top functional area journals like Administrative Science Quarterly, Strategic Management Journal, and Journal of Marketing, among others. Hence, editorial board representations in these functional area journals may also potentially carry important implications in gauging the progress of IB programs. ${ }^{21}$

Future research efforts in ranking schools with international business programs may be directed to examining the productivity of faculty in different schools across the globe in a more recent time period. Thus, future research may extend the study of Morrison and Inkpen (1991) to include more IB related journals. The challenge in conducting productivity-based research ranking is the increasing number of IB journals in recent years and the inter-disciplinary nature of the IB area.

Our ranking study using editorial board memberships is evidently an alternative approach in ranking schools with an international business program. This study provides a useful complement to the survey results of Ball and McCulloch $(1984,1988)$ and productivitybased Morrison and Inkpen (1991), and offers with a different approach to discover new insights into rankings of schools for the international business discipline.

\footnotetext{
${ }^{20}$ We believe that excluding self-citations would distort the true results of our analysis. The leading IB journal, JIBS, dominates the citations and has many self-citations. Thus, the impact factor of JIBS will be unfairly lowered if we do not count self-citations.

${ }^{21}$ There are apparently a number of non-IB scholars serving on editorial boards of these top functional area journals. To include these top-functional journals editorial board members without identifying who should be considered an IB scholar would definitely introduce different kinds of biases.
} 


\section{References}

Ball, Donald A. and Wendell H. McCulloch, Jr., 1984. International business education programs in American schools: how they are ranked by members of the Academy of International Business, Journal of International Business Studies, 15, 175-180.

Ball, Donald A. and Wendell H. McCulloch, Jr., 1988. International business education programs in American and non-American schools: how they are ranked by the Academy of International Business, Journal of International Business Studies, 19, 295-299.

Borokhovich, K.A., R.J. Bricker, K.R. Brunarski, and B.S. Simkins, 1995. Finance research productivity and influence, Journal of Finance, 50, 1691-1717.

Chan, Kam C., Carl R. Chen, and Thomas L. Steiner, 2002. Production in the finance literature, institutional reputation, and labor mobility in academia: a global perspective, Financial Management, 31, 131-156.

Chan, Kam C. and Robert Fok, 2003. Membership on editorial boards and finance department rankings, Journal of Financial Research, 26, 405-420.

Chandy, P.R. and Thomas G.E. Williams, 1994. The impact of journals and authors on international business research: a citational analysis of JIBS articles, Journal of International Business Studies, 25, 715-728.

Coe, R.K. and I. Weinstocks, I., 1983. Evaluating the finance journals: the department chairperson perspective, Journal of Financial Research, 6, 345-349.

Conboy, M.E., R. Dusansky, D. Drukker, and K. Kildegaard, 1995. The productivity of economics departments in the U.S.: publications in the core journals, Journal of Economic Literature 33, 1966-1971.

Cottingham, J., and R. Hussey, 2000. Publishing in professional accounting journals: academic institutional performance 1987-1996, The British Accounting Review, 32, 101-114.

Douglas, Susan P., 1989. The ranking of masters programs in international business: comment, Journal of International Business, 20, 157-162.

Dubois, Frank L. and David Reeb, 2000, Ranking the international business journals, Journal of International Business Studies, 31, 689-704.

Dubois, Frank L. and David Reeb, 2001, Ranking the international business journals: A reply, Journal of International Business Studies, 32, 197-199.

Gibbons, Jean D., 1990. U.S. institutional representation on editorial boards of U.S. statistics journals, American Statistician 44, 210-213. 
Gibbons, Jean D. and Mary Fish, 1991. Rankings of economics faculties and representation on editorial boards of top journals, Journal of Economic Education, 22, 361-366.

Hult, G., M. Tomas, W. T. Neese, and R. E. Bashaw, 1997. Faculty perceptions of marketing journals, Journal of Marketing Education, 19, 37-52.

Inkpen, Andrew C. and Paul W. Beamish, 1994. An analysis of twenty-five years of research in the Journal of International Business Studies, Journal of International Business Studies, 25, 703-713.

Inkpen, Andrew C., 2001. A note on ranking the international business journals, Journal of International Business Studies, 32, 193-196.

Kaufman, George, 1984. Rankings of finance departments by faculty representation on editorial boards of professional journals: a note, Journal of Finance, 39, 1189-1197.

Kurtz, David L. and Louis E. Boone, 1988, Rating marketing faculties on the basis of editorial review board membership, Journal of Marketing Education, 10, 64-68.

Mabry, Rodney H., Arthur D. Sharplin, 1985. The relative importance of journals used in finance research, Journal of Financial Research, 8, 287-296.

Mittermaier, Linda J., 1991. Representation on editorial boards of academic accounting journals: an analysis of accounting faculties and doctorial programs, Issues in Accounting Education, 6, 221-238.

Morrison, Allen J. and Andrew C. Inkpen, 1991. An analysis of significant contributions to the international business literature, Journal of International Business Studies, 22, 143-153.

Nehrt, Lee C., 1987, The ranking of masters programs in international business, Journal of International Business Studies, 18, 91-99.

Nehrt, Lee C., J. Frederick Truitt, and Richard W. Wright, 1970. International business research: past, present, and future. Bloomington, Indiana: Indiana University Bureau of Business Research.

Phene, Anupama and Stephen Guisinger, 1998. The stature of the Journal of International Business Studies, Journal of International Business Studies, 29, 621-632.

Pierce, Barbara and Garnet Garven, 1995. Publishing international business research: a survey of leading journals, Journal of International Business Studies, 26, 69-89.

Powers, Thomas L., John E. Swan, Theodore Bos, and John Frank Patton, 1998, Career research productivity patterns of marketing academicians, Journal of Business Research, 42, 7586. 
Wright, Richard W. and David A. Ricks, 1994. Trends in international business research: twentyfive years later, Journal of International Business Studies, 25, 687-701. 


\section{Table 1. Geographical location of editorial board memberships}

This table displays the geographical location of editorial board membership for the international business discipline among academic institutions. Two points are noteworthy. U.S. plays the leading role in the IB profession with the largest board memberships and the highest number of different faculty. Non-U.S. schools, as a whole, also significantly contribute to the IB profession.

\begin{tabular}{|c|c|c|c|c|}
\hline & Country & $\begin{array}{l}\text { No. of editorial } \\
\text { board members }\end{array}$ & $\begin{array}{l}\text { No. of } \\
\text { different } \\
\text { journals }\end{array}$ & $\begin{array}{l}\text { No. of } \\
\text { different } \\
\text { faculty }\end{array}$ \\
\hline \multirow{3}{*}{$\begin{array}{l}\text { North } \\
\text { America }\end{array}$} & U.S. & 1991 & 29 & 778 \\
\hline & Canada & 171.5 & 25 & 61 \\
\hline & Subtotal & $2162.5(63.13 \%)$ & & \\
\hline \multirow{15}{*}{$\begin{array}{l}\text { Asia and } \\
\text { Pacific }\end{array}$} & Australia & 96 & 21 & 47 \\
\hline & Japan & 74 & 19 & 39 \\
\hline & Hong Kong & 40 & 15 & 24 \\
\hline & South Korea & 21 & 9 & 11 \\
\hline & New Zealand & 18 & 9 & 11 \\
\hline & Singapore & 16 & 7 & 9 \\
\hline & India & 13 & 5 & 8 \\
\hline & Saudi Arabia & 12 & 5 & 6 \\
\hline & Taiwan & 12 & 4 & 8 \\
\hline & China & 8.5 & 5 & 6 \\
\hline & Thailand & 6 & 2 & 3 \\
\hline & Kuwait & 2 & 2 & 1 \\
\hline & Malaysia & 1 & 1 & 1 \\
\hline & Philippines & 1 & 1 & 1 \\
\hline & Subtotal & $320.5(9.36 \%)$ & & \\
\hline \multirow[t]{18}{*}{ Europe } & U.K. & 237.5 & 27 & 116 \\
\hline & France & 106.5 & 19 & 52 \\
\hline & Germany & 84.5 & 15 & 37 \\
\hline & The Netherlands & 73 & 17 & 33 \\
\hline & Sweden & 62.5 & 14 & 23 \\
\hline & Belgium & 46 & 9 & 17 \\
\hline & Switzerland & 41 & 14 & 22 \\
\hline & Norway & 25 & 9 & 8 \\
\hline & Spain & 23 & 10 & 13 \\
\hline & Finland & 21 & 8 & 9 \\
\hline & Denmark & 20.5 & 11 & 15 \\
\hline & Turkey & 16 & 5 & 7 \\
\hline & Poland & 15 & 8 & 6 \\
\hline & Italy & 12 & 7 & 5 \\
\hline & Ireland & 11 & 5 & 4 \\
\hline & Hungary & 8 & 4 & 5 \\
\hline & Portugal & 8 & 3 & 3 \\
\hline & Greece & 6.5 & 5 & 4 \\
\hline
\end{tabular}




\begin{tabular}{|c|c|c|c|c|}
\hline & Country & $\begin{array}{l}\text { No. of editorial } \\
\text { board members }\end{array}$ & $\begin{array}{l}\text { No. of } \\
\text { different } \\
\text { journals }\end{array}$ & $\begin{array}{l}\text { No. of } \\
\text { different } \\
\text { faculty }\end{array}$ \\
\hline & Austria & 6 & 4 & 4 \\
\hline & Russia & 5 & 3 & 2 \\
\hline & Cyprus & 4 & 2 & 3 \\
\hline & Malta & 3 & 1 & 1 \\
\hline & Romania & 3 & 1 & 1 \\
\hline & Subtotal & $838(24.46 \%)$ & & \\
\hline \multirow{17}{*}{$\begin{array}{l}\text { Others } \\
\text { (South } \\
\text { America, } \\
\text { Africa, } \\
\text { Middle } \\
\text { East) }\end{array}$} & Israel & 39.5 & 11 & 16 \\
\hline & Mexico & 14 & 7 & 5 \\
\hline & Brazil & 10 & 5 & 6 \\
\hline & Nigeria & 7.5 & 3 & 3 \\
\hline & Argentina & 5 & 2 & 2 \\
\hline & Egypt & 4.5 & 3 & 3 \\
\hline & Kenya & 4 & 1 & 1 \\
\hline & Jordan & 3 & 1 & 1 \\
\hline & Monaco & 3 & 1 & 1 \\
\hline & South Africa & 3 & 1 & 1 \\
\hline & Venezuela & 3 & 1 & 2 \\
\hline & Bolivia & 2 & 1 & 1 \\
\hline & Colombia & 2 & 2 & 2 \\
\hline & Trinidad and Tobago & 2 & 1 & 2 \\
\hline & Ghana & 1 & 1 & 1 \\
\hline & Peru & 1 & 1 & 1 \\
\hline & Subtotal & $104.5(3.05 \%)$ & & \\
\hline
\end{tabular}


Table 2. Ranking of institutions by representation on international business journals editorial boards in 1990, 1994, 1998, and 2002

This table presents the ranking of institutions by number of editorial board memberships in 30 IB journals in 1990, 1994, 1998, and 2002. Column (1) provides the frequency counts of the editorial board memberships. Columns (2) and (3) give the number of different journals and the number of different individuals from each institution that make up the editorial boards.

\begin{tabular}{|c|c|c|c|c|c|c|}
\hline Rank & Institutions & $\begin{array}{l}\text { No. of } \\
\text { editorial } \\
\text { board } \\
\text { members }\end{array}$ & $\begin{array}{l}\text { No. of } \\
\text { different } \\
\text { journals }\end{array}$ & $\begin{array}{l}\text { No. of } \\
\text { different } \\
\text { faculty }\end{array}$ & $\begin{array}{l}\text { U.S. News } \\
\text { and World } \\
\text { Report } \\
\text { graduate } \\
\text { ranking as } \\
\text { of Jan } 2003\end{array}$ & $\begin{array}{l}\text { Morrison } \\
\text { and Inkpen } \\
(1991) \\
\text { ranking (p. } \\
148)\end{array}$ \\
\hline 1 & Michigan State U & 67 & 17 & 28 & 20 & \\
\hline 2 & New York U & 65 & 12 & 20 & 5 & 6 \\
\hline 3 & Columbia U & 57 & 10 & 36 & 3 (tied) & 1 \\
\hline 4 & $\begin{array}{l}\text { American Graduate School of } \\
\text { International Business }\end{array}$ & 55 & 13 & 19 & 1 & \\
\hline 5 & U of South Carolina & 52 & 14 & 17 & 2 & 5 \\
\hline 6 & U of Michigan & 51 & 16 & 18 & 6 & 11 \\
\hline 7 & INSEAD, France & 43.5 & 12 & 20 & & 19 \\
\hline 8 & Penn State U & 43 & 11 & 10 & & 22 \\
\hline 9 & Georgetown U & 39 & 13 & 11 & 14 & 8 \\
\hline 10 & Rutgers U & 38.5 & 15 & 17 & & 4 \\
\hline 11 & U of Illinois, Urbana-Champaign & 39 & 11 & 20 & & 23 \\
\hline 12 & U of Penn & 38 & 10 & 21 & 3 (tied) & 2 \\
\hline 13 & London Business School, UK & 37 & 11 & 16 & & \\
\hline 14 & U of New South Wales, Australia & 35 & 12 & 18 & & \\
\hline 15 & Indiana U & 33.5 & 12 & 10 & 15 & 21 \\
\hline 16 (tied) & $\begin{array}{l}\text { City U of New York (Baruch } \\
\text { College) }\end{array}$ & 33 & 11 & 9 & & 14 \\
\hline 16 (tied) & Temple U & 33 & 12 & 14 & 22 (tied) & \\
\hline 18 & U of Texas, Austin & 31.5 & 10 & 11 & 16 & 12 \\
\hline
\end{tabular}




\begin{tabular}{|c|c|c|c|c|c|c|}
\hline Rank & Institutions & $\begin{array}{l}\text { No. of } \\
\text { editorial } \\
\text { board } \\
\text { members }\end{array}$ & $\begin{array}{l}\text { No. of } \\
\text { different } \\
\text { journals }\end{array}$ & $\begin{array}{l}\text { No. of } \\
\text { different } \\
\text { faculty }\end{array}$ & $\begin{array}{l}\text { U.S. News } \\
\text { and World } \\
\text { Report } \\
\text { graduate } \\
\text { ranking as } \\
\text { of Jan } 2003\end{array}$ & $\begin{array}{l}\text { Morrison } \\
\text { and Inkpen } \\
(1991) \\
\text { ranking (p. } \\
148)\end{array}$ \\
\hline 19 (tied) & Northwestern U & 29 & 6 & 13 & 11 & \\
\hline 19 (tied) & Simon Fraser U, Canada & 29 & 12 & 7 & & 18 \\
\hline 19 (tied) & U of Reading, UK & 29 & 9 & 7 & & \\
\hline 22 & Harvard U & 26 & 10 & 16 & 7 & 3 \\
\hline 23 (tied) & Texas A\&M U & 24 & 11 & 9 & & 25 \\
\hline 23 (tied) & U of Maryland & 24 & 9 & 7 & & \\
\hline 25 & $\begin{array}{l}\text { Stockholm School of Economics, } \\
\text { Sweden }\end{array}$ & 23 & 8 & 8 & & \\
\hline 26 & U of Washington & 22 & 8 & 9 & 22 (tied) & \\
\hline 27 (tied) & Ohio State U & 21 & 11 & 9 & & 20 \\
\hline 27 (tied) & U of California, Irvine & 21 & 9 & 6 & & \\
\hline 29 (tied) & Chinese U. of Hong Kong & 20 & 9 & 10 & & \\
\hline 29 (tied) & Florida International U & 20 & 9 & 8 & & \\
\hline 29 (tied) & U of Wisconsin, Madison & 20 & 9 & 7 & & \\
\hline 32 & U of California, Los Angeles & 19.5 & 6 & 8 & 10 & \\
\hline 33 (tied) & Concordia U, Canada & 19 & 8 & 7 & & \\
\hline 33 (tied) & McGill U, Canada & 19 & 7 & 2 & & 9 \\
\hline 35 (tied) & Arizona State U & 18 & 9 & 9 & & \\
\hline 35 (tied) & Drexel U & 18 & 7 & 7 & & \\
\hline 35 (tied) & Emory U & 18 & 10 & 7 & & \\
\hline 35 (tied) & Erasmus U, The Netherlands & 18 & 8 & 12 & & \\
\hline 39 (tied) & John Carroll U & 17 & 8 & 1 & & \\
\hline 39 (tied) & Kent State U & 17 & 11 & 3 & & \\
\hline 39 (tied) & U of Groningen, The Netherlands & 17 & 5 & 4 & & \\
\hline 39 (tied) & U of Missouri-Columbia & 17 & 7 & 9 & & \\
\hline 39 (tied) & U of Western Ontario, Canada & 17 & 6 & 6 & & 10 \\
\hline
\end{tabular}




\begin{tabular}{|c|c|c|c|c|c|c|}
\hline Rank & Institutions & $\begin{array}{l}\text { No. of } \\
\text { editorial } \\
\text { board } \\
\text { members }\end{array}$ & $\begin{array}{l}\text { No. of } \\
\text { different } \\
\text { journals }\end{array}$ & $\begin{array}{l}\text { No. of } \\
\text { different } \\
\text { faculty }\end{array}$ & $\begin{array}{l}\text { U.S. News } \\
\text { and World } \\
\text { Report } \\
\text { graduate } \\
\text { ranking as } \\
\text { of Jan } 2003 \\
\end{array}$ & $\begin{array}{l}\text { Morrison } \\
\text { and Inkpen } \\
(1991) \\
\text { ranking (p. } \\
148)\end{array}$ \\
\hline 44 (tied) & California State U, Fresno & 16 & 2 & 7 & & \\
\hline 44 (tied) & U of Miami & 16 & 7 & 8 & & \\
\hline 44 (tied) & U of Toronto, Canada & 16 & 8 & 5 & & \\
\hline 47 & Tel Aviv U, Israel & 15.5 & 7 & 8 & & 16 \\
\hline 48 & U of Southern California & 14.5 & 7 & 7 & 12 & 7 \\
\hline 49 (tied) & Brigham Young U & 14 & 5 & 2 & & \\
\hline 49 (tied) & Texas A\&M International U & 14 & 2 & 5 & & \\
\hline \multirow[t]{2}{*}{49 (tied) } & Uppsala U, Sweden & 14 & 3 & 4 & & \\
\hline & $\begin{array}{l}636 \text { institutions have } 13 \text { or less } \\
\text { editorial board membership }\end{array}$ & & & & & \\
\hline
\end{tabular}



Table 3. Impact factor-based editorial board index rankings 1990, 1994, 1998, and 2002 for editorial boards of $30 \mathrm{IB}$ journals

This table presents the ranking of institutions based on the impact factor-based editorial board index (EBI). The EBI of an institution is defined as:

$$
\mathrm{EBI}=\sum_{\mathrm{i}=1}^{30} \underset{\mathrm{t}=1}{\sum} \mathrm{f}_{\mathrm{it}} * \mathrm{IF}_{\mathrm{it}}
$$

where $\mathrm{f}_{\mathrm{it}}=$ the frequency of the editorial memberships in $\mathrm{i}^{\text {th }}$ journal at time $\mathrm{t}$.

\begin{tabular}{|c|c|c|c|c|}
\hline $\begin{array}{c}\text { Rank } \\
\text { (based on } \\
\text { EBI (t-2)) }\end{array}$ & Institutions & EBI (t-2) & EBI (t-5) & $\begin{array}{c}\text { Rank } \\
\text { (based on } \\
\text { EBI (t-5)) }\end{array}$ \\
\hline 1 & U of South Carolina & 7.0321 & 8.7242 & 1 \\
\hline 2 & New York U & 6.1642 & 7.5918 & 2 \\
\hline 3 & Georgetown U & 5.5117 & 6.3585 & 4 \\
\hline 4 & U of Reading, UK & 5.3879 & 7.0252 & 3 \\
\hline 5 & U of Pennsylvania & 5.0928 & 5.6449 & 8 \\
\hline 6 & Michigan State U & 4.5607 & 5.9482 & 6 \\
\hline 7 & London Business School, UK & 4.4285 & 5.9734 & 5 \\
\hline 8 & Indiana U & 4.4192 & 5.9258 & 7 \\
\hline 9 & Rutgers U & 4.2451 & 5.2539 & 9 \\
\hline 10 & U of Michigan & 3.7766 & 4.7480 & 11 \\
\hline 11 & Thunderbird U & 3.6139 & 4.6635 & 12 \\
\hline 12 & U of Western Ontario, Canada & 3.4720 & 4.8233 & 10 \\
\hline 13 & Harvard U & 3.3480 & 4.4561 & 13 \\
\hline 14 & U of Washington & 2.8782 & 3.0797 & 15 \\
\hline 15 & U of Texas, Austin & 2.7236 & 2.8358 & 18 \\
\hline 16 & McGill U, Canada & 2.5916 & 2.4701 & 23 \\
\hline 17 & U of Minnesota & 2.3982 & 3.5291 & 14 \\
\hline 18 & U of Illinois, Urbana-Champaign & 2.2737 & 2.5169 & 21 \\
\hline 19 & U of Toronto, Canada & 2.1746 & 2.8859 & 17 \\
\hline 20 & John Carroll U & 2.1640 & 2.2143 & 32 \\
\hline 21 & Fordham U & 2.0877 & 2.2169 & 31 \\
\hline 22 & Laval U, Canada & 2.0221 & 2.0810 & 36 \\
\hline 23 & U of Leeds, UK & 1.9834 & 2.4999 & 22 \\
\hline 24 & INSEAD, France & 1.9235 & 2.7057 & 19 \\
\hline 25 & U of Oklahoma & 1.8716 & 1.9829 & 38 \\
\hline 26 & California Polytechnic State U & 1.8617 & 1.9918 & 37 \\
\hline 27 & U of California, Irvine & 1.8356 & 1.3171 & 61 \\
\hline 28 & U of Miami & 1.7811 & 2.2908 & 27 \\
\hline 29 & U of New South Wales, Australia & 1.7517 & 1.6026 & 51 \\
\hline 30 & Temple U & 1.7111 & 3.0098 & 16 \\
\hline 31 & Columbia U & 1.6567 & 2.2583 & 29 \\
\hline 32 & U College Dublin, Ireland & 1.6421 & 1.9457 & 40 \\
\hline 33 & Ohio State U & 1.4533 & 2.6416 & 20 \\
\hline
\end{tabular}

$\mathrm{IF}_{\mathrm{it}}=$ impact factor of the $\mathrm{i}^{\text {th }}$ journal at time $\mathrm{t}$.

The impact factors in 1990, 1994, 1998, and 2002 are reported in the Appendices 1 and 2. 


\begin{tabular}{|c|l|c|c|c|}
\hline $\begin{array}{c}\text { Rank } \\
\text { (based on } \\
\text { EBI (t-2)) }\end{array}$ & Institutions & EBI (t-2) & EBI (t-5) & $\begin{array}{c}\text { Rank } \\
\text { (based on } \\
\text { EBI (t-5)) }\end{array}$ \\
\hline 34 & Simon Fraser U, Canada & 1.4458 & 2.1233 & 33 \\
\hline 35 & U of Wisconsin, Madison & 1.4316 & 1.6086 & 49 \\
\hline 36 & U Hohenheim, Germany & 1.4143 & 2.3660 & 25 \\
\hline 37 & Pennsylvania State U & 1.3987 & 2.0843 & 35 \\
\hline 38 & Kent State U & 1.3974 & 2.2243 & 30 \\
\hline 39 & U of Virginia & 1.3342 & 1.2784 & 62 \\
\hline & Stockholm School of Economics, & & & \\
\hline 40 & Sweden & 1.2950 & 2.3843 & 24 \\
\hline 41 & U of Antwerp, Belgium & 1.2681 & 1.9804 & 39 \\
\hline 42 & Brigham Young U & 1.2616 & 1.9291 & 42 \\
\hline 43 (tied) & Korea U & 1.2231 & 1.1859 & 65 (tied) \\
\hline 43 (tied) & Versailles Saint-Quentin U, France & 1.2231 & 1.1859 & 65 (tied) \\
\hline 45 & U of Richmond & 1.2172 & 1.0001 & 83 \\
\hline 46 & Northwestern U & 1.1768 & 2.2789 & 28 \\
\hline 47 & U of Strachclyde, UK & 1.1688 & 2.3241 & 26 \\
\hline 48 & Vrije U of Brussels, Belgium & 1.1197 & 1.5262 & 34 \\
\hline 49 & Concordia U, Canada & 1.1175 & 1.8634 & 44 \\
\hline 50 & Texas A\&M U & 282 institutions & 476 institutions & \\
\hline & & have EBI (t-2) & have EBI (t-5) & \\
\hline & & & & \\
\hline & & below 1.1175 & & \\
\hline
\end{tabular}




\section{Table 4. Determinants of editorial board representation}

This table presents a regression model of finding the common characteristics among the top-100 institutions based on representation in editorial memberships in IB programs. We use the top-100 schools in Tables 2 and 3 as the samples. Because of tied ranking, there are more than 100 schools in the sample. $* 10 \%$ significant, $* * 5 \%$ significant, and *** $1 \%$ significant; VIF is the variance inflation factor. The variable definitions are:

AACSB = AACSB accreditation (Yes = 1 ; otherwise 0 );

IB = Stand alone IB program (Yes = 1 ; otherwise 0$)$;

Doctoral $=$ Doctoral program (highest IB degree offered is doctorate $=1$; otherwise 0 );

Master = Master program (highest IB degree is master $=1$; otherwise 0 );

Bachelor = Bachelor program (highest IB degree is bachelor =1; otherwise 0);

Public = Public institution (public institution =1; otherwise 0 );

MBA = MBA ranking from Financial Times (1 is highest);

Location = Location of the institution (US and Canada $=1$; otherwise 0 );

JIBS = Number of JIBS articles published in 1990-2002;

Board = editorial board membership;

EBI $(\mathrm{t}-2)$ = editorial board index that uses $(\mathrm{t}-2)$ years impact factors;

EBI $(\mathrm{t}-5)$ = editorial board index that uses (t-5) years impact factors;

Panel A: Correlation coefficients among variables in the regression model

\begin{tabular}{|c|c|c|c|c|c|c|c|c|c|c|c|c|}
\hline Variables & AACSB & IB & Doctoral & Master & Bachelor & Public & MBA & Location & JIBS & Board & EBI (t-2) & EBI (t-5) \\
\hline AACSB & -- & & & & & & & & & & & \\
\hline IB & 0.0442 & -- & & & & & & & & & & \\
\hline Doctoral & 0.1150 & 0.4089 & -- & & & & & & & & & \\
\hline Master & 0.0249 & 0.1799 & -0.3923 & -- & & & & & & & & \\
\hline Bachelor & 0.1670 & -0.0355 & -0.1714 & -0.2421 & -- & & & & & & & \\
\hline Public & -0.1997 & -0.0364 & 0.0633 & -0.1531 & -0.1516 & -- & & & & & & \\
\hline MBA & -0.1731 & 0.0395 & -0.2098 & 0.1323 & 0.1275 & 0.0546 & -- & & & & & \\
\hline Location & 0.5078 & 0.1565 & 0.1301 & 0.1249 & 0.0643 & -0.2174 & -0.1860 & -- & & & & \\
\hline JIBS & -0.0177 & 0.1546 & 0.3424 & -0.1355 & -0.0775 & -0.0108 & -0.3639 & 0.1294 & -- & & & \\
\hline Board & 0.0645 & 0.3053 & 0.4579 & -0.1373 & -0.1615 & -0.0558 & -0.4678 & 0.1453 & 0.5386 & -- & & \\
\hline EBI (t-2) & -0.0160 & 0.1460 & 0.3572 & -0.1854 & -0.1353 & -0.0845 & -0.4118 & 0.0963 & 0.7051 & 0.7387 & -- & \\
\hline EBI (t-5) & -0.0724 & 0.1771 & 0.3733 & -0.1899 & -0.1342 & -0.0274 & -0.4075 & 0.0845 & 0.7239 & 0.7546 & 0.9769 & -- \\
\hline
\end{tabular}


Panel B: Regression analysis

\begin{tabular}{|c|c|c|c|c|c|c|c|c|c|c|}
\hline & & \multicolumn{9}{|c|}{ Dependent variables } \\
\hline & & \multicolumn{3}{|c|}{ Editorial board memberships } & \multicolumn{3}{|c|}{$\mathrm{EBI}(\mathrm{t}-2)$} & \multicolumn{3}{|c|}{ EBI (t-5) } \\
\hline Variables & $\begin{array}{l}\text { Expected } \\
\text { sign }\end{array}$ & $\begin{array}{c}\text { Estimated } \\
\text { coefficient }\end{array}$ & $\begin{array}{c}\mathrm{t}- \\
\text { statistics }\end{array}$ & VIF & $\begin{array}{c}\text { Estimated } \\
\text { coefficient }\end{array}$ & $\begin{array}{c}\mathrm{t}- \\
\text { statistics }\end{array}$ & VIF & $\begin{array}{c}\text { Estimated } \\
\text { coefficient }\end{array}$ & $\begin{array}{c}\mathrm{t}- \\
\text { statistics }\end{array}$ & VIF \\
\hline Intercept & & 19.2050 & $5.08 * * *$ & 0 & 1.5640 & $4.77 * * *$ & 0 & 1.8385 & $3.88 * * *$ & 0 \\
\hline AACSB & + & -0.1656 & -0.06 & 1.47 & -0.2604 & -0.88 & 1.56 & -0.4576 & -1.35 & 1.46 \\
\hline IB & + & 5.3066 & $2.31 * *$ & 1.54 & 0.2631 & 1.01 & 1.63 & 0.4160 & 1.41 & 1.61 \\
\hline Doctoral & + & 5.4256 & $1.68 *$ & 2.12 & 0.1043 & 0.29 & 2.27 & 0.1355 & 0.32 & 2.21 \\
\hline Master & ? & -1.3531 & -0.53 & 1.82 & -0.4065 & -1.41 & 1.81 & -0.3933 & -1.21 & 1.82 \\
\hline Bachelor & - & -3.5775 & -0.98 & 1.37 & -0.4455 & -1.10 & 1.42 & -0.4555 & -0.96 & 1.37 \\
\hline Public & ? & -1.8430 & -0.83 & 1.12 & -0.3632 & -1.44 & 1.15 & -0.2302 & -0.82 & 1.21 \\
\hline MBA & - & -0.0126 & $-3.81 * * *$ & 1.28 & -0.0008 & $-2.23 * *$ & 1.31 & -0.0011 & $-2.57 * *$ & 1.29 \\
\hline Location & ? & -0.1885 & -0.08 & 1.47 & -0.0593 & -0.21 & 1.56 & -0.0498 & -0.16 & 1.48 \\
\hline JIBS & + & 1.5897 & $4.05^{* * *}$ & 1.30 & 0.3213 & $7.71 * * *$ & 1.28 & 0.4101 & $8.35 * * *$ & 1.29 \\
\hline F-statistics & & $10.75^{* * *}$ & & & $13.23^{* * *}$ & & & $15.77 * * *$ & & \\
\hline R-square & & 0.4795 & & & 0.5642 & & & 0.5843 & & \\
\hline $\mathrm{N}$ & & 115 & & & 102 & & & 111 & & \\
\hline
\end{tabular}




\section{Table 5. Rank correlation coefficients among various rankings}

This table presents the rank correlation analyses among various rankings. Panel A reports the correlation for different criteria using all the 332 institutions (both academic and non-academic). Panel B reports the rank correlation between the ranking of U.S. News and World Report and the rankings in this study

Panel A: Editorial board memberships and EBI rankings

\begin{tabular}{|c|c|c|c|}
\hline & $\begin{array}{c}\text { All schools that } \\
\text { have EBI (t-2) } \\
\mathbf{N}=332\end{array}$ & $\begin{array}{c}\text { All schools that } \\
\text { have EBI (t-5) } \\
\mathbf{N = 5 2 6}\end{array}$ & $\begin{array}{c}\text { Top 25 schools in } \\
\text { Table 3 }\end{array}$ \\
\hline $\begin{array}{c}\text { Editorial board } \\
\text { membership } \\
\text { ranking }\end{array}$ & 0.5203 & 0.5883 & 0.6808 \\
\hline
\end{tabular}

Panel B: U.S. News and World Report top 23 schools, Morrison and Inkpen top-25 schools (in Table 3 of Morrison and Inkpen (1991, p. 148), and Inkpen and Beamish top-25 schools during 1970-1994 (in Table 4 of Inkpen and Beamish (1994, p. 709) (Note: the $9^{\text {th }}$ ranked University of California-Berkeley and $17^{\text {th }}$ ranked University of Chicago were deleted because they had no faculty represented in the 30 IB journals)

\begin{tabular}{|c|c|c|c|}
\hline Ranking criteria & $\begin{array}{c}\text { No. of editorial } \\
\text { board members }\end{array}$ & EBI (t-2) & EBI (t-5) \\
\hline $\begin{array}{c}\text { US News and World Report } \\
\text { Top 23 schools as of Jan 2003 }\end{array}$ & 0.1565 & 0.2151 & 0.2118 \\
\hline Morrison and Inkpen (1991) & 0.1645 & 0.1430 & 0.1571 \\
\hline Inkpen and Beamish (1994) & 0.2928 & 0.3724 & 0.5892 \\
\hline
\end{tabular}


Table 6. Leading international business professionals by representation on editorial boards of $30 \mathrm{IB}$ journals in 1990, 1994, 1998, and 2002

Panel A identifies leading IB professionals in terms of the number of editorial board memberships. Panel B ranks names by the impact factor-based editorial board index.

Panel A: By editorial board membership

\begin{tabular}{|c|c|c|c|c|}
\hline Rank & Name & $\begin{array}{l}\text { Institutional } \\
\text { affiliation as of } \\
\text { December, } 2002\end{array}$ & $\begin{array}{l}\text { No. of } \\
\text { editorial } \\
\text { memberships }\end{array}$ & $\begin{array}{l}\text { No. of } \\
\text { different } \\
\text { journals }\end{array}$ \\
\hline 1 & Aggarwal, Raj & Kent State U & 23 & 8 \\
\hline 2 & Kaynak, Erdener & Penn State U & 20 & 6 \\
\hline 3 (tied) & Cavusgil, S. Tamer & Michigan State U & 18 & 8 \\
\hline 3 (tied) & Ricks, David A. & $\begin{array}{l}\text { U of Missouri, St. } \\
\text { Louis }\end{array}$ & 18 & 8 \\
\hline 5 & Boddewyn, Jean J. & City U of New York & 17 & 6 \\
\hline 6 & Kotabe, Masaaki "Mike" & Temple U & 14 & 7 \\
\hline 7 (tied) & Czinkota, Michael R. & Georgetown U & 13 & 6 \\
\hline 7 (tied) & Radebaugh, Lee H. & Brigham Young U & 13 & 5 \\
\hline 7 (tied) & Samiee, Saeed & U of Tulsa & 13 & 5 \\
\hline 7 (tied) & Thorelli, Hans B. & Indian U & 13 & 5 \\
\hline 11 & Tung, Rosalie L. & Simon Fraser U & 12 & 6 \\
\hline 12 (tied) & Daniels, John D. & U of Miami & 11 & 4 \\
\hline 12 (tied) & Rice, Gillian & $\begin{array}{l}\text { American Graduate } \\
\text { School of } \\
\text { International Business }\end{array}$ & 11 & 3 \\
\hline 12 (tied) & Rugman, Alan M. & $\begin{array}{l}\text { Indiana } \mathrm{U} / \mathrm{U} \text { of } \\
\text { Oxford }\end{array}$ & 11 & 7 \\
\hline 12 (tied) & Terpstra, Vern & U of Michigan & 11 & 5 \\
\hline 16 (tied) & Adler, Nancy J. & McGill U, Canada & 10 & 4 \\
\hline 16 (tied) & Beamish, Paul M. & $\begin{array}{l}\text { U of Western Ontario, } \\
\text { Canada }\end{array}$ & 10 & 5 \\
\hline 16 (tied) & Booth, G. Geoffrey & Michigan State U & 10 & 4 \\
\hline 16 (tied) & Cassion, Mark C. & U of Reading, UK & 10 & 3 \\
\hline 16 (tied) & Douglas, Susan P. & New York U & 10 & 3 \\
\hline 16 (tied) & Dunning, John H. & $\begin{array}{l}\text { Rutgers U / U of } \\
\text { Reading, UK }\end{array}$ & 10 & 4 \\
\hline 16 (tied) & Ghauri, Pervez N. & $\begin{array}{l}\text { U of Groningen, the } \\
\text { Netherlands }\end{array}$ & 10 & 3 \\
\hline 16 (tied) & Kumar, Brij Nino & $\begin{array}{l}\text { Friedrich-Alexander } \\
\text { U, Germany }\end{array}$ & 10 & 4 \\
\hline 16 (tied) & Ortiz, Edgar & $\begin{array}{l}\text { U Nacional Autonoma } \\
\text { de Mexico }\end{array}$ & 10 & 3 \\
\hline 16 (tied) & Sheth, Jagdish N. & Emory U & 10 & 4 \\
\hline 16 (tied) & Stulz, Rene & Ohio State U & 10 & 3 \\
\hline
\end{tabular}


Panel B: By impact factor-based editorial board index (EBI (t-2))

\begin{tabular}{|c|l|l|c|}
\hline Rank & Name & $\begin{array}{c}\text { Institutional affiliation as } \\
\text { of December, 2002 }\end{array}$ & EBI (t-2) \\
\hline 1 & Aggarwal, Raj & Kent State U & 2.7857 \\
\hline 2 & Douglas, Susan P. & New York U & 2.7040 \\
\hline 3 & Adler, Nancy J. & McGill U, Canada & 2.5916 \\
\hline 4 & Hennart, Jean Francois & Tilburg U, the Netherlands & 2.5239 \\
\hline 5 & Cassion, Mark C. & U of Reading, UK & 2.4342 \\
\hline 6 & Daniels, John D. & U of Miami & 2.1056 \\
\hline 7 & Egelhoff, William G. & Fordham U & 2.0877 \\
\hline 8 & Cosset, Jean-Claude & Laval U, Canada & 2.0221 \\
\hline 9 & Cavusgil, S. Tamer & Michigan State U & 1.9102 \\
\hline & & California Polytechnic State & \\
\hline 10 & Geringer, J. Michael & U & 1.8617 \\
\hline 11 & Dunning, John H. & $\begin{array}{l}\text { Rutgers U / U of Reading, } \\
\text { UK }\end{array}$ & 1.8459 \\
\hline 12 & Earley, P. Christopher & Indiana U & 1.7925 \\
\hline 13 & Harvey, Michael G. & U of Mississippi & 1.7775 \\
\hline 14 & Contractor, Farouk J. & Rutgers U & 1.7230 \\
\hline 15 & Cantwell, John A. & U of Reading, UK & 1.7113 \\
\hline 16 & Bradley, Frank & U College Dublin, Ireland & 1.6421 \\
\hline 17 & Thorelli, Hans B. & Indiana U & 1.5631 \\
\hline & & $\begin{array}{l}\text { American Graduate School } \\
\text { of International Business }\end{array}$ & 1.5575 \\
\hline 18 & Grosse, Robert E. & Georgetown U & 1.5319 \\
\hline 19 (tied) & Brewer, Thomas L. & U of Toronto, Canada & 1.5319 \\
\hline 19 (tied) & Booth, Laurence D. & & \\
\hline
\end{tabular}




\section{Appendix 1. International business journal impact factors (t-2)}

The impact factors in Table 2 are calculated from citations from five core IB journals (Journal of International Business Studies, Management International Review, Journal of World Business, Multinational Business Review, and International Business Review) in 1990, 1994, 1998, and 2002.

\begin{tabular}{|c|c|c|c|c|c|}
\hline Journal & $\begin{array}{l}\text { Short } \\
\text { name }\end{array}$ & $\begin{array}{l}\text { Impact } \\
\text { factor } \\
90 \\
\end{array}$ & $\begin{array}{l}\text { Impact } \\
\text { factor } \\
94 \\
\end{array}$ & $\begin{array}{l}\text { Impact } \\
\text { factor } \\
98 \\
\end{array}$ & $\begin{array}{l}\text { Impact } \\
\text { factor } \\
2002 \\
\end{array}$ \\
\hline Advances in International Accounting & AIA & 0 & 0 & 0 & 0 \\
\hline $\begin{array}{l}\text { Advances in International Banking and } \\
\text { Finance }\end{array}$ & AIBF & 0 & 0 & 0 & 0 \\
\hline $\begin{array}{l}\text { Advances in International Comparative } \\
\text { Management }\end{array}$ & AICM & 0 & 0 & 0 & 0 \\
\hline Advances in International Marketing & AIM & 0 & 0 & 0 & 0 \\
\hline Global Finance J & GFJ & 0 & 0 & 0 & 0 \\
\hline International Business Review & IBR & 0 & 0.1000 & 0.1194 & 0.0816 \\
\hline International J of Accounting & IJA & 0 & 0 & 0 & 0 \\
\hline International J of Conflict Management & IJCM & 0 & 0 & 0 & 0 \\
\hline International J of Finance & IJF & 0 & 0 & 0 & 0 \\
\hline International J of Management & IJM & 0 & 0 & 0 & 0 \\
\hline International J of Research in Marketing & IJRM & 0 & 0 & 0 & 0 \\
\hline International Management & $\mathrm{IM}$ & 0 & 0.0059 & 0 & 0 \\
\hline International Marketing Review & IMR & 0.0943 & 0 & 0.0175 & 0.0294 \\
\hline $\begin{array}{l}\text { International Review of Strategic } \\
\text { Management }\end{array}$ & IRSM & 0 & 0 & 0 & 0 \\
\hline $\begin{array}{l}\text { International Studies of Management and } \\
\text { Organization }\end{array}$ & ISMO & 0 & 0 & 0 & 0 \\
\hline International Trade $J$ & ITJ & 0.0303 & 0.0909 & 0.0000 & 0.0000 \\
\hline J of Global Marketing & JGM & 0 & 0 & 0.0250 & 0.0513 \\
\hline J of International Business Studies & JIBS & 0.4902 & 0.3088 & 0.8649 & 0.3582 \\
\hline$J$ of International Consumer marketing & JICM & 0 & 0 & 0 & 0 \\
\hline J of International Finance & JIF & 0 & 0 & 0 & 0 \\
\hline $\begin{array}{l}\text { J of International Financial Management } \\
\text { and Accounting }\end{array}$ & JIFMA & 0 & 0 & 0 & 0 \\
\hline J of International Management & JOIM & 0 & 0 & 0.0400 & 0.0256 \\
\hline J of International Marketing & JIM & 0 & 0.0233 & 0.0377 & 0.0492 \\
\hline $\begin{array}{l}\text { J of International Marketing and } \\
\text { Marketing Research }\end{array}$ & JIMMR & 0 & 0 & 0 & 0 \\
\hline J of Multinational Financial Management & JMFM & 0 & 0 & 0 & 0 \\
\hline J of World Business & JWB & 0.0423 & 0.0220 & 0.2653 & 0.2642 \\
\hline Management International Review & MIR & 0.2200 & 0.0645 & 0.2162 & 0.1818 \\
\hline Multinational Business Review & MBR & 0 & 0 & 0 & 0.1111 \\
\hline Multinational Finance $J$ & MFJ & 0 & 0 & 0 & 0 \\
\hline $\begin{array}{l}\text { Thunderbird International Business } \\
\text { Review }\end{array}$ & TIBR & 0 & 0 & 0 & 0 \\
\hline
\end{tabular}




\section{Appendix 2. International business journal impact factors (t-5)}

The impact factors in Table 2 are calculated from citations from five core IB journals (Journal of International Business Studies, Management International Review, Journal of World Business, Multinational Business Review, and International Business Review) in 1990, 1994, 1998, and 2002.

\begin{tabular}{|c|c|c|c|c|c|}
\hline Journal & $\begin{array}{l}\text { Short } \\
\text { name }\end{array}$ & $\begin{array}{l}\text { Impact } \\
\text { factor } 90\end{array}$ & $\begin{array}{l}\text { Impact } \\
\text { factor } 94\end{array}$ & $\begin{array}{l}\text { Impact } \\
\text { factor } 98\end{array}$ & $\begin{array}{l}\text { Impact } \\
\text { factor } \\
2002 \\
\end{array}$ \\
\hline Advances in International Accounting & AIA & 0 & 0 & 0 & 0 \\
\hline $\begin{array}{l}\text { Advances in International Banking and } \\
\text { Finance }\end{array}$ & AIBF & 0 & 0 & 0 & 0 \\
\hline $\begin{array}{l}\text { Advances in International Comparative } \\
\text { Management }\end{array}$ & AICM & 0 & 0 & 0 & 0.0167 \\
\hline Advances in International Marketing & AIM & 0.0500 & 0.0250 & 0.0250 & 0 \\
\hline Global Finance $J$ & GFJ & 0.2000 & 0 & 0 & 0.0125 \\
\hline International Business Review & IBR & 0 & 0.1250 & 0.1250 & 0.1923 \\
\hline International J of Accounting & IJA & 0 & 0.0066 & 0.0066 & 0 \\
\hline International J of Conflict Management & IJCM & 0 & 0 & 0 & 0.0282 \\
\hline International $J$ of Finance & IJF & 0 & 0 & 0 & 0 \\
\hline International J of Management & IJM & 0 & 0 & 0 & 0 \\
\hline International J of Research in Marketing & IJRM & 0.0098 & 0.0090 & 0.0090 & 0.0085 \\
\hline International Management & IM & 0 & 0.0040 & 0.0020 & 0 \\
\hline International Marketing Review & IMR & 0.0224 & 0.0827 & 0.0827 & 0.0207 \\
\hline $\begin{array}{l}\text { International Review of Strategic } \\
\text { Management }\end{array}$ & IRSM & 0 & 0 & 0 & 0 \\
\hline $\begin{array}{l}\text { International Studies of Management and } \\
\text { Organization }\end{array}$ & ISMO & 0.0094 & 0 & 0 & 0.0579 \\
\hline International Trade $J$ & ITJ & 0.0159 & 0.0366 & 0 & 0 \\
\hline J of Global Marketing & JGM & & 0.0240 & 0.0240 & 0.0606 \\
\hline J of International Business Studies & JIBS & 0.4545 & 0.4406 & 0.4406 & 0.6695 \\
\hline J of International Consumer marketing & JICM & 0 & 0 & 0 & 0.0122 \\
\hline J of International Finance & JIF & 0 & 0 & 0 & 0 \\
\hline $\begin{array}{l}J \text { of International Financial Management } \\
\text { and Accounting }\end{array}$ & JIFMA & 0 & 0 & 0 & 0 \\
\hline J of International Management & JOIM & 0 & 0 & 0.0159 & 0.1200 \\
\hline J of International Marketing & JIM & 0 & 0.0500 & 0.0500 & 0.0948 \\
\hline $\begin{array}{l}\text { J of International Marketing and } \\
\text { Marketing Research }\end{array}$ & JIMMR & 0 & 0 & 0 & 0 \\
\hline J of Multinational Financial Management & JMFM & 0 & 0 & 0 & 0 \\
\hline J of World Business & JWB & 0.0435 & 0.0690 & 0.0690 & 0.2295 \\
\hline Management International Review & MIR & 0.1346 & 0.2464 & 0.2464 & 0.4118 \\
\hline Multinational Business Review & MBR & 0 & 0 & 0 & 0.0926 \\
\hline Multinational Finance $J$ & MFJ & 0 & 0 & 0 & 0 \\
\hline $\begin{array}{l}\text { Thunderbird International Business } \\
\text { Review }\end{array}$ & TIBR & 0 & 0 & 0 & 0.0072 \\
\hline
\end{tabular}




\section{Appendix 3. Top-25 IB programs based on publications in Journal of International Business Studies (1990-2002)}

We hand-collected the information from JIBS during 1990-2002 and counted the number of JIBS articles published by respective institutions. If the numbers of articles are the same, we use the number of school appearance as the tiebreaker.

\begin{tabular}{|c|c|c|c|}
\hline Rank & Institutions & \begin{tabular}{|l} 
Number of \\
articles
\end{tabular} & $\begin{array}{l}\text { Number of } \\
\text { appearances }\end{array}$ \\
\hline 1 & U South Carolina & 15.25 & 32 \\
\hline 2 & U Western Ontario, Canada & 12.92 & 27 \\
\hline 3 & U Texas-Austin & 8.87 & 19 \\
\hline 4 & U Pennsylvania & 8.50 & 12 \\
\hline 5 & Georgetown U & 8.25 & 16 \\
\hline 6 & $\begin{array}{l}\text { Chinese University of Hong Kong, } \\
\text { Hong Kong }\end{array}$ & 8.08 & 21 \\
\hline 7 & Harvard U & 7.83 & 10 \\
\hline 8 & Rutgers U & 7.17 & 15 \\
\hline 9 & U Hawaii & 7.00 & 14 \\
\hline 10 & New York U & 6.35 & 11 \\
\hline 11 & $\begin{array}{l}\text { American Graduate School of } \\
\text { International Management }\end{array}$ & 6.08 & 11 \\
\hline 12 & INSEAD, France & 6.08 & 9 \\
\hline 13 & U Oklahoma & 5.37 & 8 \\
\hline 14 & U Minnesota & 4.75 & 9 \\
\hline 15 & Indiana U & 4.70 & 8 \\
\hline 16 & Michigan State U & 4.67 & 12 \\
\hline 17 & American U & 4.50 & 9 \\
\hline 18 & Northeastern U & 4.33 & 8 \\
\hline 19 & University of Hong Kong, Hong Kong & 4.20 & 12 \\
\hline 20 & Iowa State U & 4.17 & 9 \\
\hline 21 & Ohio State U & 4.08 & 8 \\
\hline 22 & Temple U & 4.00 & 10 \\
\hline 23 & U Washington & 4.00 & 8 \\
\hline 24 & U Bradford, UK & 4.00 & 7 \\
\hline 25 & U Miami & 3.67 & 6 \\
\hline 26 & Dartmouth College & 3.50 & 8 \\
\hline 28 (tied) & U Leeds, UK & 3.50 & 7 \\
\hline 28 (tied) & U Texas-Dallas & 3.50 & 7 \\
\hline 28 (tied) & UC-Irvine & 3.50 & 7 \\
\hline 30 & Baruch College & 3.50 & 6 \\
\hline 30 & U Toronto & 3.50 & 6 \\
\hline 32 & U Reading & 3.50 & 5 \\
\hline
\end{tabular}




\begin{tabular}{|c|l|c|c|}
\hline Rank & Institutions & $\begin{array}{l}\text { Number of } \\
\text { articles }\end{array}$ & $\begin{array}{l}\text { Number of } \\
\text { appearances }\end{array}$ \\
\hline 33 & Tilburg U & 3.25 & 6 \\
\hline & Stockholm School Economics, & & \\
\hline 34 & Sweden & 3.17 & 6 \\
\hline 35 & Boise State U & 3.17 & 5 \\
\hline 36 & Simon Fraser U, Canada & 3.12 & 7 \\
\hline 37 (tied) & London Business School, UK & 3.00 & 7 \\
\hline 37 (tied) & Texas A\&M U & 3.00 & 7 \\
\hline 39 & Boston U & 3.00 & 3 \\
\hline 40 & U Texas-San Antonio & 2.83 & 7 \\
\hline 41 & Purdue U & 2.83 & 4 \\
\hline 42 & U Houston & 2.79 & 9 \\
\hline 43 & U Pittsburgh & 2.67 & 6 \\
\hline 44 & U Utah & 2.67 & 5 \\
\hline 45 & U Michigan & 2.50 & 6 \\
\hline & Hong Kong Polytechnic U, Hong & & \\
\hline 46 & Kong & 2.50 & 5 \\
\hline & Copenhagen Business School, & & \\
\hline 47 & Denmark & 2.50 & 4 \\
\hline 48 (tied) & Penn State U & 2.50 & 3 \\
\hline 48 (tied) & U Tulsa & 2.50 & 3 \\
\hline 50 & Nanyang Technological U, Singapore & 2.42 & 5 \\
\hline
\end{tabular}

